\title{
Sergio Franzese Reader of James
}

\section{Sarin Marchetti}

\section{OpenEdition}

\section{Journals}

Electronic version

URL: http://journals.openedition.org/ejpap/1023

DOI: 10.4000/ejpap.1023

ISSN: 2036-4091

\section{Publisher}

Associazione Pragma

\section{Electronic reference}

Sarin Marchetti, «Sergio Franzese Reader of James », European Journal of Pragmatism and American Philosophy [Online], II-2 | 2010, Online since 21 December 2010, connection on 10 May 2019. URL http://journals.openedition.org/ejpap/1023 ; DOI : 10.4000/ejpap.1023

This text was automatically generated on 10 May 2019

\section{(c) (i) $\odot$}

Author retains copyright and grants the European Journal of Pragmatism and American Philosophy right of first publication with the work simultaneously licensed under a Creative Commons AttributionNonCommercial-NoDerivatives 4.0 International License. 


\title{
Sergio Franzese Reader of James
}

\author{
Sarin Marchetti
}

1 Sergio Franzese (1963-2010) has been one among the most active and interesting scholars of William James in Europe. His intellectual biography is in fact shaped by an ongoing dialogue with the thought and writings of James, which guided both his incursions into the work of Nietzsche as well as the examinations of the conversations between pragmatism, Darwinism and phenomenology. Besides many fine books - both authored and edited - on James, he was also the translator and editor of the Italian edition of three volumes by James: Pragmatism (Torino, Aragno, 2007), Essays in Radical Empiricism (Milano, Il Saggiatore, 1994; and Macerata, Quodlibet 2009) and Great Men and Their Environment (Pisa, ETS 1995). In what follows I shall try to canvass his personal stroll with James by reviewing his two most recent authored books. In particular, what I would like to do is conveying both the importance and the novelty of his work for the understanding of some intriguing neglected paths in James' works, an inquiry abruptly interrupted by Sergio's premature death.

2 The leitmotiv of Franzese's earlier and later work on James is the investigation of his philosophical anthropology and its bearings for ethics. Carving out James' anthropological considerations from his writings on psychology, religion and pragmatism requires both a confident mastery of James' impressive corpus of writings, and, most importantly, a precise insight into James' own ideas about the very shape such an anthropology should take. Franzese's books exhibit both, since they cover a great amount of material maintaining a stringent interpretative hypothesis on the way such material gathers together. The author handles with confidence a vast array of writings, suggesting how we should orientate through them by combining together accurate historical reconstructions and suggestive theoretical speculation.

In The Ethics of Energy. William James's Moral Philosophy in Focus (Frankfurt, Ontos Verlag, 2008), Franzese explores with both great accuracy and insight James' inquiry into the nature of moral philosophy. This book represents the foremost and brightest account of this topic, and it also constitutes, in our opinion, the finest product among Franzese's writings. Furthermore, this theme represents an interest permeating Franzese's other 
writings, whose investigations brought him to engage in the reading of Nietzsche as well as of the American transcendentalists. In the book the author sketches James' philosophical anthropology and investigates the intricate conception of ethics emerging from it. Drawing from some materials already explored in his L'Uomo Indeterminato. Saggio su William James (Roma, D'Anselmi Editore, 2000) Franzese argues for a deep entanglement between James' pragmatic image of the self and his anti-foundational understanding of ethics. It is in fact James' widespread contention that the acknowledgement of the nature of one's mindedness and worldliness is a necessary condition for the investigation of what morality altogether could and should look like. There are a variety of ways in which James explores this entanglement, and Franzese accounts for it by contesting the readings that the commentators gave to some pivotal texts of James in which it surfaces. In particular, a major text in which James tackles the question of the nature of morality is The Moral Philosopher and the Moral Life. This essay is very important since in it we can find both the essence of James' understanding of moral philosophy and the defense of a precise outline of his philosophical anthropology. Despite being widely recognized by the vast majority of the secondary literature as the presentation of James' moral theory, most notably after Ralph Burton Perry's commentary of it in his monumental The Thought and Character of William James (Boston, Brown and Little, 1935), this text questions the very possibility of a theoretical account of morality. According to the author, the image that James is resisting is precisely that of moral reflection as the advancement of a normative system of principles and goods, and he reads the dialectic of the essay as debunking the very possibility of any foundation of morality - being it psychological, metaphysical or casuistic. The book proceeds from a detailed analysis of the essay and traces the seeds for such a deceived reading in the very misunderstanding of James' underlying philosophical anthropology. He claims in fact that an attentive look at James' companion writings on the practical nature of our mental life uncovers some aspects of James' philosophical anthropology laying on the background of his ethical writings, whose grasping would reorient the very reading of these texts as theoretical accounts of moral principles and goods. In this direction Franzese draws a comparison between James' experimental science, according to which ethics deals with the human attempts to organize their own energies in order to make sense of the 'emotional involvement in the values to be exalted' (p. 45), and Lotze's value-laden microcosmic view. Both views share the primacy of action and practical considerations in the very description of the mind's pursuit of truth and meanings, and this leads in James' case to the characterization of moral reflection as a descriptive inquiry into the very psychology of the agents involved.

In this context Franzese's detailed analysis of James' critique of the associationist school, and of utilitarianism in the specific $(22-6,106-19)$ is particularly useful. According to Franzese, in fact, the moral psychology implicit in this school reveals the kind of veiled foundational anxieties haunting the (Newtonian) British empiricist tradition in its craving for the discovery of an unique psychological mechanism for the explanation of our moral life, being it that of pleasure association in the benthamite understanding, or that of habitual internalization of social emotions à la Bain. Even if the discussion - both James' and Franzese's - of this tradition is sometimes superficial - it is in fact a shame that James so abruptly dismissed Hume's or Mill's subtle treatments of the matter, and that Franzese didn't take in consideration the fine work on those authors that has been produced in the last twenty years - still the general point sounds interesting and worth investigating. James is in fact critical of the empiricist tradition for the way it characterized the entanglement between psychology and ethics, even if he pays tribute for its 
accomplishments and inscribes himself in that very tradition. It is well know his characterization of his own empiricism as radical, and Franzese traces the radicality of James' position into its very description of the mental life. If the late Essays on Radical Empiricism represents James' most technical and refined treatment of such an empiricism, the seeds of his position can be traced into his earlier writings on the nature of experience and experiencing, and also in the moral writings allegedly pictured as presenting a normative defense of a moral theory. In particular, the discussion of the psychological, metaphysical and casuistic questions in The Moral Philosopher and the Moral Life aims at debunking the traditional image of moral reflection as the search of a normative principle for the explanation of our moral practices. According to James, the empiricist tradition misplaced the role of the philosopher in respect to the moral experiences he should investigate, and Franzese claims that the real stakes of the essay is precisely that of showing the shortcomings of such a misplacement (p. 35-40).

5 The author claims that, according to James, the proper field where moral thought should be investigated is that of philosophical anthropology; that is, the moral philosopher should be a keen observer of human nature in order to describe its features and limitations, both physiological and cultural. However, being such an anthropology barely explicit in James' writings, Franzese carves it out from the very details of James' treatment of mindedness and worldliness. In the second chapter of the book he discusses the nature of James' pragmatic anthropology and assess its stakes in respect to others anthropological positions (49-81). He uses in particular The Principles of Psychology and Talks to Teachers, in which James presents his philosophy of mind in a pragmatic mood. Franzese notices that these works are suffused with moral instructions, or, rather, that James' pragmatic anthropology is moved by moral concerns, and thus he concentrates in particular on its expression in James' treatment of habit and its bearings for ethics. It is by discussing this aspect of James' work that the author sketches an interpretative reconstruction of his pragmatic anthropology, in which physiological, psychological and teleological considerations merge into a pragmatic account of the self as a center of storing, organizing and controlling of energy. According to this provocative reading, James' scattered but widespread remarks on the energies of men represent the cornerstone for understanding his anthropological image, which from its part calls for 'an ethics of energy,' as the book titles. According to Franzese, the most distinctive move James operates in this direction is that of re-orienting the whole discussion of habit, rescuing it from the mechanicistic shoals in which it has been placed by the empiricist tradition and portraying it as the brightest expression of the practical character of our minds. By defining the character in terms of the will, and in its turn the will in terms of habit, James establishes a robust connection between the shaping of one's own character with the care of one's habit through the education of one's will. This moral psychology marks a deep discontinuity with the tradition James inherited, since it inscribes practical considerations into the very heart of the simples mental activities, reverting the usual link between ethics and psychology: it is not that practical considerations supervene on psychological ones, but rather psychological descriptions are already value laden, since according to James our psychological constitution is directly relevant for the articulation of our moral life.

6 The author presents this aspect of James' thought insisting on the deep entanglement between ethical constitution and psychological constitution. He writes that "hortatory ethics is almost the only relevant aspect of moral philosophy about which we can soundly 
speak, and such an ethics has its most power ally in the knowledge of the physiological constitution of human beings. The aim of such an ethics is, of course, some sort of 'good"' (129). And after quoting James' most provocative claim according to which the way we take care of our mental life is the utmost important ethical act, he comments that according to James, ethics allies with physiology in showing the way to the good life, which consists above all in a well structured and well disposed personality' (ibid.). This is the very background against which Franzese proceeds in his presentation of the ethics of energy originating from such a pragmatic anthropology. As Franzese recognizes in the first place, the reconstruction of such an ethics is highly speculative for two order of considerations: firstly because James himself was very tentative in the elaboration of such a project, and secondly - and most importantly - because of the very character of such an ethics. If in fact James criticizes the conception of moral reflection as the advancement of moral theories, then it is no surprise that his ethics doesn't resemble to standard moral theory. The last two chapters of the book are dedicated to the presentation of the very physiognomy of this energetic ethics; while the fourth explores the theme of energy in its metaphysical and anthropological dimensions, the fifth presents the way in which James understands energy and how this conception is relevant for the articulation of the moral discourse. Through an attentive analysis of some passages from The Varieties of Religious Experience, in which James explicitly suggests the deep connection between a description of human beings in terms of their energetic temperament - the strenuous as opposed to the genial mood- and their ethical constitution - the ethics of heroism as opposed to the ethics of spirituality, Franzese carves out a picture of human beings as torn between nature and culture, where these two terms are pragmatically re-interpreted to converge in the 'human anomaly' (164-79).

In his collection of essays Darwinismo e Pragmatismo (Milano, Mimesis, 2009) Franzese explicitly addresses the question of James' pragmatic anthropology by assessing the place of the Darwinian revolution in James' intellectual development. The continuity with the previous work is explicit, and in the essays constituting the book the author tackles the very same connection from different perspectives. The first four chapters deal in fact with the varieties of relationships that James' anthropology establishes with both Darwinism and American transcendentalism. The title essay traces the influences of Darwinism on pragmatism, from the birth of the Metaphysical Club to the later developments of the American movement. In particular, the section on James' engagement with Darwinism concentrates on the kind of interest Darwinism exercised on James. If in fact James was a Darwinian, he was not a Darwinist. We have a direct - and somewhat intimate - testimony of James' relationship with Darwin himself in a 1883 letter wrote to Darwin's son Erasmus, translated with a short commentary by the author in the book under discussion. The letter consists in a response to Erasmus' request to James to have some elucidations about the relationship between his father's moral ideas and Francis Abbot's. Given the great friendship running between James and Erasmus, the tone of the letter is charming, but its contents are not for this reason less rigorous. As Franzese notices, James' response is revealing of the kind of reading James gave of Darwin, and its bearings on his own philosophical position. What kept James' imagination is not Darwin's theory of evolution per se, but rather its anthropological and ethical consequences: the Darwinian temperament expressed from such a theory, more than its principles by themselves. According to James, as we can also read in the letter quoted, the importance of Darwin has been that of liberating our minds from a frame of thought picturing the human being as a product of necessities overcoming its own chances and 
contingencies, debunking in a single stroke the whole metaphysical tradition rooted in western philosophy. As the author notices, James' radicality is exhibited by his early philosophical production and is concerned with a defense of human spontaneity from the threads of Spencerian evolutionism, which represented at that time a ground-breaking philosophical application of this anti-metaphysical theme. What James founds unsatisfactory in Spencer's conception of the mind as the adaptation of inner with outer happenings for the sake of surviving are its ethical consequences; namely, the negation of the personal contribute to our experiencing which escapes from this monistic teleology. By nestling interests and selective attention into the very mechanisms of our human minds James resists the mechanistic variation of evolutionism in favor of the Darwinian accent of chance variation and generative selection. Franzese traces this trajectory in James' production pointing in particular to his two essays The Great Men and their Environment and The Importance of Individuals, in which James defends Darwin's idea that the environmental setting is only a conservative and not a productive cause of the variation of individuals. Franzese tackles this theme in the second essay of the book, in which such a Darwinian influence is presented together with the other source of inspiration which characterized James' early education: that is his own reading of the transcendentalism of Emerson and Caryle. According to the author, it is fair to describe James' anthropological views as informed by the double source of American transcendentalism and Darwinism, which finds in his thought a virtuous synthesis. In his 1903 address to the centenary of Emerson's birth James praised the man for his service paid to the valorization of personal experiences and experimentations for the cultivation of one's self, according to which 'imitation is suicide' and 'the day is good in which we have the most perceptions.' Even if the two traditions of Darwinism and transcendentalism hardly found any robust direct historical connections, still they both inform the American life at the turn of the century, and James, after Franzese, can be read as a thinker who tried to balance both these irruptive conceptions of the self.

8 The author, in the ninth piece, titled Il Pragmatismo è un Umanesimo. Anti-Filosofia e Filosofia dell'Esperienza, presents pragmatism itself as driven by concerns expressed by both traditions. By gathering together a variety of authors as different as Nietzsche and Peirce - to which the author dedicated the edited volume Nietzsche e l'America (Pisa: Ets 2005) the author depicts James' pragmatism as a distinctive voice that is however echoed in a general attitude to the treatment of philosophical questions. The author moves from the characterization of pragmatism as engaged in the elaboration of a philosophical anthropology to the characterization of pragmatism as a method for the resolution of philosophical disputes and themes. However the shift is only apparent, since the two characterizations are deeply intertwined and illuminates each other. A sample of this intertwinement is given by the compelling characterization of James' pragmatic conception of truth. He writes: "agency determines the horizon of meaningfulness of language by discriminating what is meaningful from what is not. This has immediate bearings for the question of truth. The task is not that of deciding about the ways and criteria according to which we arrive at truths - a task fulfilled by epistemology - but rather that of understanding what does it mean to speak of truth. That is, what is the stance we take toward truth itself. Truth is not thus a vague metaphysical term, but rather it acquires sense on the background of an agential landscape. In such a perspective, for the pragmatist the contrary of truth is not falsity but rather what is irrelevant; that is, that to which it doesn't correspond any concrete practice" (207). By portraying agency as the condition of meaningfulness of our practices of truth and truth 
as a goal which requires the very exercise of our agency, James draws a close connection between a pragmatic anthropological image of human beings as agents and a pragmatic conception of "truth as leading". Such a connection, which represents a major theme in James' works, is presented by Franzese as the clearest expression of the pragmatic temperament guiding his philosophy. It is on the background of this connection that the ethical question should be addressed.

9 James' scholarship, less alive if compared with that of other figures of classical pragmatism such as Peirce and Dewey, is presently growing, thanks also to the work of historians and psychology scholars. Sergio's work represents a precious endowment for those interested in contributing to this field. It egregiously accomplishes two difficult tasks at once: it both conveys a compelling picture of James' philosophical anthropology and stimulates further reflections for our present debate about the nature of morality and its relationship with philosophical anthropology.

\section{AUTHOR}

\section{SARIN MARCHETTI}

Sapienza Università di Roma and Columbia University

sarin.marchetti[at]gmail.com 